\title{
1 Viability of greenhouse gas removal via the artificial addition of volcanic
}

2 ash to the ocean

3 Jack Longmana, ${ }^{\text {b,c*, }}$ Martin R. Palmer ${ }^{\mathrm{b}}$, Thomas M. Gernon ${ }^{\mathrm{b}}$

$4{ }^{\text {a }}$ Marine Isotope Geochemistry, Institute for Chemistry and Biology of the Marine

5 Environment (ICBM), University of Oldenburg, PO Box 2503, 26111 Oldenburg, Germany

6 b School of Ocean and Earth Sciences, University of Southampton, Southampton SO14 3ZH,

7 UK

$8{ }^{c}$ School of Geography and the Environment, University of Oxford, South Parks Road,

9 Oxford, OX1 3QY, UK

10 *Corresponding Author: jack.longman@uni-oldenburg.de

11 Abstract

Attempts to mitigate human contributions to climate change have become a highly debated topic, as it becomes evident that optional global emission reductions are not being adhered to by many nations. Therefore, substantial research is taking place into negative carbon technologies that actively reduce the amount of atmospheric carbon dioxide $\left(\mathrm{CO}_{2}\right)$, via greenhouse gas removal (GGR). Various GGR methods have been proposed, from reforestation to ocean fertilisation. Here, we discuss the advantages of an approach based on the enhanced input of tephra to the ocean, to increase the drawdown of atmospheric $\mathrm{CO}_{2}$. Natural addition of tephra to the ocean results in enhanced organic matter preservation in sediment; hence augmenting its delivery should raise the level of sequestration. Our calculations indicate offshore tephra addition could sequester 2750 tonnes of $\mathrm{CO}_{2}$ per 50,000 tonnes of ash delivered (a typical bulk carrier's capacity). The cost is estimated to be $\sim \$ 55$ per tonne of $\mathrm{CO}_{2}$ sequestered and is an order of magnitude cheaper than many other proposed GGR technologies. Further advantages include; tephra addition is simply an augmentation of a natural Earth process, it is a low technology approach that requires few developments, and it may sequester carbon for thousands of years. Hence, we suggest offshore tephra addition warrants further investigation to assess its viability. 
Greenhouse Gas Removal, geoengineering, offshore tephra addition, volcanic ash, diagenesis, climate change

\section{Introduction}

Proposals have recently been made to remediate human contributions to climate change through geoengineering, leading to considerable discussion of the topic (Royal Society, 2018). To ensure the world stays below the IPCC upper limit to "safe" warming (IPCC, 2018), additional measures other than non-binding agreements will be required (Haszeldine et al., 2018; Tollefson, 2018). Hence, Greenhouse Gas Removal (GGR), via geoengineering, has been posited to reduce levels of anthropogenic carbon dioxide $\left(\mathrm{CO}_{2}\right)$ in the atmosphere, thus avoiding large-scale impacts of climate change such as ecosystem collapse and major changes in ocean circulation (Lomax et al., 2015; Steffen et al., 2018).

A variety of GGR methods have been proposed, from reforestation and habitat restoration (e.g. (e.g. Bastin et al., 2019), to infrastructural changes, such as low-carbon concrete production (Ghouleh et al., 2017) and the use of biomass in building materials (e.g. Ramage et al., 2016). Other GGR proposals involve enhancing the rate at which the Earth's natural carbon cycle sequesters atmospheric $\mathrm{CO}_{2}$ in natural sinks (Royal Society, 2018). Examples of natural cycle manipulation include increasing the alkalinity of the ocean (i.e., reversing ocean acidification (Renforth and Henderson, 2017)), enhancing mineral carbonation (i.e., converting silicate rocks into carbonates (Matter et al., 2016)) and ocean fertilization (i.e., enhancing photosynthetic carbon removal (Boyd et al., 2007)).

All proposed GGR interventions have associated risks, and face scientific, economic and societal barriers to implementation. For example, repurposing terrestrial biomass for carbon sequestration necessarily requires the utilization of agricultural land currently used to produce food. Manipulation of natural cycles also suffer from an unpalatable image due to perceived meddling with the natural world, and potential impacts on ecosystems (Royal Society, 2018). 
54 No single mechanism of emissions reduction or GGR can feasibly halt the rise in atmospheric $\mathrm{CO}_{2}$ levels (Royal Society, 2018), so it is beneficial to consider a range of emissions reduction and GGR strategies that have lesser risks and implementation barriers, rather than adoption of a single big impact, high-risk strategy. Hence, we present a potential GGR mechanism based on enhanced input of the products of explosive volcanism (Figure 1) into the oceans. This approach builds on the role that natural tephra deposition in the oceans plays in the carbon cycle (Figure 2) (Longman et al., 2019) and examines the potential enhancement of these natural processes to achieve GGR. Based on real-world data, we calculate the potential of the proposed method to sequester atmospheric carbon, and provide an estimate of likely costs.

\section{The Approach}

It is estimated that the global amount of organic carbon $\left(\mathrm{C}_{\text {org }}\right)$ reaching the seafloor is equivalent to $8.4 \mathrm{Gt} \mathrm{CO}_{2} \mathrm{a}^{-1}$, of which $\sim 13 \%$ is buried and $87 \%$ returned to the oceanatmosphere (Burdige, 2007). The variety of processes controlling the $\mathrm{C}_{\text {org }}$ burial efficiency enhances CBE (Longman et al., 2019), outlined below.

\section{Fertilization} phytoplankton growth (Olgun et al., 2011). This process has been the subject of extensive study (e.g., see Olgun et al. (2011) and Duggen et al. (2010) for reviews). For example, phytoplankton blooms occurred when tephra was deposited in the nutrient-poor NE Pacific Ocean following eruption of Kasatochi volcano (Langmann et al., 2010; Olgun et al., 2011), in the vicinity of the Mariana Islands following the 2003 Anatahan eruption (Lin et al., 2011), 
Southern Pacific after the eruption of Pinatubo in 1991 (Siegenthaler and Sarmiento, 1993).

Other research suggests subduction zone-related ash deposition may play a role in controlling productivity (Duggen et al., 2007). In each case, the increased productivity sequestered $\mathrm{CO}_{2}$ from the ocean-atmosphere. For example, the 2008 eruption of Kasatochi led to the export of 0.01 Pg carbon from the upper ocean (Hamme et al., 2010). Carbon was removed from the upper oceans when phytoplankton (and their consumers) settled out of the upper ocean and into the deep ocean (the 'biological pump'; Sarmiento and Gruber, 2006). In addition to accelerating the rate of the biological pump (Fig. 2), tephra deposition in the surface oceans also likely enhances the transport of organic carbon $\left(\mathrm{C}_{\text {org }}\right)$ from surface oceans into deeper water because plankton debris may become physically associated with the negatively buoyant particles (e.g., Rubin et al., 2011). This leads to the incorporation of dense, Fe-rich dust (and by analogy tephra) in algal colonies, ballasting the tephra and enhancing sinking rates (Pabortsava et al., 2017).

\section{Dissolved Oxygen $\left(\mathrm{O}_{2}\right)$ consumption}

Much of the Fe contained within tephra is in the form of $\mathrm{Fe}^{\mathrm{II}}$ (Maters et al., 2017), which is highly reactive and rapidly oxidized to $\mathrm{Fe}^{\mathrm{III}}$ through pore water $\mathrm{O}_{2}$ consumption. This process also occurs during tephra transport through the water column, but due to ballasting tephra settling rates are too fast for this to be significant, leading to the export of a large proportion of $\mathrm{Fe}^{\mathrm{II}}$ to the sediment (Hembury et al., 2012). Once sufficient tephra (i.e., a layer $>0.5 \mathrm{~cm}$ thick) accumulates on the ocean floor, oxidation of $\mathrm{Fe}^{\mathrm{II}}$ in the tephra causes dissolved $\mathrm{O}_{2}$ concentrations fall to zero within sediment pore waters, reducing the exposure of the newly deposited $\mathrm{C}_{\text {org }}$ to oxidative processes (Haeckel et al., 2001; Hembury et al., 2012). Because the oxidation of labile $\mathrm{C}_{\text {org }}$ in marine sediments is critically dependent on dissolved $\mathrm{O}_{2}$ levels in pore water (Hartnett et al., 1998), the presence of tephra likely enhances $\mathrm{C}_{\text {org }}$ preservation in sediments and further sequesters $\mathrm{CO}_{2}$ from the ocean-atmosphere system (Fig. 2). 
Tephra contains high concentrations of reactive Fe Mn and Al (Homoky et al., 2011). These reactive phases form stable colloids with $\mathrm{C}_{\text {org }}$ (Lalonde et al., 2012), inhibiting $\mathrm{C}_{\text {org }}$ oxidation and enhancing preservation (Fig. 2). Notably, the colloid-- $\mathrm{C}_{\text {org }}$ complexes are sufficiently stable to protect $\mathrm{C}_{\text {org }}$ from oxidation even if they are transported from shelf environments to the deep sea (Dunne et al., 2007).

\section{Authigenic carbonate formation}

Tephra is also rich in divalent cations released into sediment pore waters during diagenesis (Gieskes, 1983; Murray et al., 2018). One proposed method of GGR is to increase ocean alkalinity, through artificial addition of divalent cations to the ocean (Kheshgi, 1995; Renforth and Henderson, 2017). Within marine sediments, cations released from tephra react with the enhanced alkalinity created by $\mathrm{C}_{\text {org }}$ oxidation, resulting in the precipitation of authigenic calcium carbonate and calcium-magnesium carbonate $\left(\mathrm{Ca}(\mathrm{Mg}) \mathrm{CO}_{3}\right)$. Again, this process effectively locks carbon derived from $\mathrm{C}_{\text {org }}$ into a form that may be stable for millennia (Schrag et al., 2013).

\section{Technology readiness}

Addition of tephra to the oceans requires no new technology and ocean fertilization experiments have proven feasible (Boyd et al., 2007). In mesoscale experiments, artificial Fe addition enhances phytoplankton productivity in high nutrient, low chlorophyll environments by alleviating Fe-related nutrient limitation (Martin and Fitzwater, 1988). Phytoplankton blooms as a result of natural tephra addition to HNLC regions have also been observed, confirming the fertilizing potential of tephra in these environments (Langmann et al., 2010; Olgun et al., 2011). The mechanisms relating to the impact of tephra within seafloor sediments indicate that sequestration of plankton-produced $\mathrm{C}_{\text {org }}$ may occur over millennial timescales, but 
an assessment of the amount of tephra deposition required to enable significant levels of carbon sequestration is required.

Most active terrestrial volcanoes produce tephra and, with the exception of Australia, it is produced on every continent (Fig. 3). Tephra is one of the most common components of global oceanic sediments, such that it comprises $\sim 25 \%$ of Pacific Ocean sediments (Scudder et al., 2016), and with an estimated yearly flux of ash to the Pacific Ocean of $0.13-0.22 \times 10^{15} \mathrm{~g} \mathrm{a}^{-1}$ (Olgun et al., 2011). Quarrying of recent tephra (optimal for this proposed method) provides aggregate for cement works and road surfaces, but supplies are not limiting. Large recent deposits of basaltic tephra are located across the globe (Fig. 3). In addition, bentonite clay (diagenetically altered tephra) mining is well-established (Eisenhour and Brown, 2009), so novel, energy-intensive, extraction techniques are not required. Most tephra extraction occurs in open pits using bucket loaders so would only require sorting of the unconsolidated tephra to grain size $<63 \mu \mathrm{m}$, the fraction containing most Fe-rich minerals (Homoky et al., 2011).

\section{Storage potential and longevity of storage}

The gross storage potential is defined here as the increase in $\mathrm{CO}_{2}$ storage resulting from tephra addition to the oceans. The net storage potential is the gross storage minus the $\mathrm{CO}_{2}$ requirement of delivering the tephra to the oceans; although the latter value is not included in most methods evaluated in the GGR Royal Society report (Royal Society, 2018).

Here, we provide an estimate of the potential carbon storage using the Peru margin as an example due to its naturally high primary productivity, resulting from upwelling of nutrientrich Pacific bottom waters (Pennington et al., 2006). The high productivity leads to depletion of $\mathrm{O}_{2}$ in the water column, and an oxygen minimum zone (OMZ) bathing sediment to depths of $400 \mathrm{~m}$ (Bohlen et al., 2011). As a result, the sediments contain up to $15 \% \mathrm{C}_{\text {org }}$ below the OMZ (Arthur et al., 1998). CBE increases from $18 \%$ on the inner shelf (with no OMZ) to average of $47 \%$ below the OMZ (Dale et al., 2015) due to the reduced oxidant exposure. 
Table 1 contains an estimate of the key parameters required to assess gross and net potential storage of $\mathrm{C}_{\text {org }}$ on the inner shelf through the addition of tephra to these sediments. In these calculations, we assume that reduced oxidant exposure in the sediments resulting from tephra addition, yields a similar increase in CBE to that resulting from the OMZ. As with all GGR strategies, there are large uncertainties in evaluating these parameters, in particular CBEs. Nevertheless, this exercise is useful for provide a comparison with other GGR strategies with similar uncertainties (Royal Society, 2018) (Table 2).

The calculated net potential removal is $\sim 2300 \mathrm{t}$ of $\mathrm{CO}_{2}$ per $50,000 \mathrm{t}$ of tephra delivered to the oceans per year. The impact of Fe fertilization has a limited duration, but each addition of tephra to the seafloor will impact $\mathrm{C}_{\text {org }}$ storage for hundreds to thousands of years. Table 1 assumes a tephra layer of $5 \mathrm{~mm}$ is required to achieve the calculated increase in CBE, but microelectrode studies of tephra deposited on the seafloor reveal that pore water dissolved $\mathrm{O}_{2}$ concentrations can fall to $<50 \%$ of bottom water levels within $1 \mathrm{~mm}$ of the sediment-water interface (Hembury et al., 2012). Thus, the dependence of CBE on dissolved $\mathrm{O}_{2}$ exposure times (Hartnett et al., 1998) would likely lead to enhanced $\mathrm{CO}_{2}$ storage even under minimal tephra loading. Note also, that the natural CBEs observed on the Peru margin are not typical of shelf sediments. The average CBE in sandy sediments, that represent $70 \%$ of the global area of continental shelves with water depths $<200 \mathrm{~m}$, is $\sim 1 \%$ (Burdige, 2007). Hence, selection of optimal seafloor sites for large increases in gross potential storage (i.e. large $\mathrm{C}_{\text {org }}$ fluxes, but low CBE, delivery of optimum amounts of tephra to achieve maximum increase in $\mathrm{C}_{\text {org }}$ preservation) and net potential storage (i.e. close to readily accessible tephra deposits) may yield potential $\mathrm{CO}_{2}$ storage rates similar to those described in Table 1. In addition, timing tephra loading to coincide with the maximum rate of $\mathrm{C}_{\text {org }}$ deposition at the sediment surface (e.g. following phytoplankton blooms) would further enhance the scale of $\mathrm{C}_{\text {org }}$ preservation. During seasonal upwelling, there is high $\mathrm{C}_{\text {org }}$ production in surface waters and fluxes to the 
seafloor, but it is largely remineralised in oxygenated nature of the bottom waters, yielding low CBEs (Dale et al., 2015). Timing tephra delivery to just after the upwelling period may result in large absolute carbon burial.

\section{Resources required}

The only processing of the tephra prior to its use would be light crushing and sorting. Spreading tephra over the ocean would require infrastructure, including loading terminals and adapted ships (i.e. with mechanisms for tephra release), but land transport costs would be low because most volcanoes are located close to the oceans (Fig. 3). Marine vessels require an energy source, but the use of redundant coal barges could reduce $\mathrm{CO}_{2}$ emissions. Freshly deposited tephra is unconsolidated and can be removed and loaded into transport using conventional excavators and trucks. In comparison to a number of other proposed GGR methods, this approach is uncomplicated (Table 2). Ocean fertilization, for example, requires the processing of $\mathrm{Fe}^{\mathrm{II}}$-rich solution (Boyd et al., 2000), and other proposals require entirely new approaches to infrastructural development (e.g. carbon capture and storage; Royal Society, 2018). In contrast, offshore tephra addition would require; i) loading of ash onto barges; ii) travel to site of optimal loading as determined via study of seafloor environment and ocean currents (see Boyd et al., 2000); and iii) release of ash in a steady manner along prescribed paths.

\section{Environmental benefits and challenges}

Ocean-wide changes in bottom water and deep-sea oxygenation levels have been invoked as one of the causes of benthic foraminiferal extinction at the Cretaceous-Tertiary boundary (e.g., Coccioni and Galeotti, 1994). Hence, it has been suggested that tephra deposition on the seafloor may have a similar on benthic communities. For example, ash fall associated with the 1991 Mt. Pinatubo eruption caused mass mortality of benthic foraminifers over a large area of the South China Sea (Hess and Kuhnt, 1996), with mortality of all benthic foraminifers at sites receiving 6-8 $\mathrm{cm}$ of tephra. In addition, there was a reduction in species diversity at sites 
receiving $\sim 2 \mathrm{~cm}$ of tephra (Hess et al., 2001; Hess and Kuhnt, 1996). However, whereas recovery of the benthic community from the K-T extinction took several thousand years (Coccioni and Galeotti, 1994), recovery of South China Sea sediments was largely complete less than 10 years after tephra deposition, even in the areas that received the thickest deposits (Hess et al., 2001; Kuhnt et al., 2005). Tephra may leach some toxic elements into the water column (Jones and Gislason, 2008), and in some circumstances can lead to a drop in the $\mathrm{pH}$ of seawater as acids are released (Frogner Kockum et al., 2006; Frogner et al., 2001). Other impacts of tephra deposition are unknown, including potential impacts on planktic, and larger organisms. However, while large scale tephra input to surface waters in the immediate vicinity of volcanoes may be harmful, there is no evidence that the initial mortality is long-lasting or widespread (Hoffmann et al., 2012; Jones and Gislason, 2008; Wall-Palmer et al., 2011). There are also examples from the geologic record showing that pre-deposition benthic ostracod species survived at least $6 \mathrm{~cm}$ of tephra deposition (Perrier et al., 2012). Nevertheless, environmental impact assessments would be required to examine ecosystem responses to enhanced tephra loading.

Tephra extraction will lead to environmental impacts on-shore, but most types of tephra are of low toxicity and the risks can be mitigated by standard procedures such as cast-back mining adopted during industrial bentonite extraction (Eisenhour and Brown, 2009).

\section{Scalability and engineering challenges}

As with ocean fertilization through iron addition, tephra fertilization should be scalable without significant cost increases. The financial cost/benefit ratio depends on the scale of operations and the site selection. Typical charter rates for $50,000 \mathrm{t}$ bulk carriers are $\sim \$ 10,000 \mathrm{~d}^{-1}$ which, for a $2000 \mathrm{~km}$ deployment at $20 \mathrm{~km} \mathrm{hr}^{-1}$ and 2 days loading (UNCTAD, 2018), yields a cost of $\sim \$ 70,000$ per deployment. Terrestrial transport costs will increase this estimate. If we assume $\sim \$ 600 \mathrm{~d}^{-1}$ to hire a 44 -tonne truck, and ten $60-\mathrm{km}$ round journeys are possible per day, then 
$\sim 68,000$ will be necessary per deployment. Even so, the estimated cost of $\$ 55$ per $\mathrm{tCO}_{2}$ deployed, based on the estimates in Table 1, is an order of magnitude lower than many other GGR technologies (Table 2, Royal Society, 2018).

\section{Monitoring and evaluation}

Many of the risks to implementation and optimization of tephra dispersal can be investigated in laboratory studies. Both natural (e.g. Hamme et al., 2010; Langmann et al., 2010; Olgun et al., 2011) and laboratory studies (e.g. Hoffmann et al., 2012; Mélançon et al., 2014) have shown that ash fertilizes phytoplankton productivity, so the primary risk is that the approach does not sufficiently raise CBEs. This question may be tackled by undertaking experiments to measure $\mathrm{C}_{\text {org }}$ degradation rates under various conditions of tephra loading and over a range of sediment types. The responses of benthic biota to tephra loading can also be investigated in laboratory studies (cf. Brown et al., 2017). Once laboratory tests are completed, small-scale in situ studies would be necessary to test the concept, with several years of monitoring.

\section{Social factors}

Natural volcanic processes transport millions of tonnes of tephra to the oceans every year, with an estimated $2.2 \times 10^{8} \mathrm{t}$ yr deposited in the Pacific Ocean alone (Olgun et al., 2011). Hence, unlike most other proposed GGR interventions, the mechanism outlined here is an augmentation to a naturally occurring process. In addition, tephra addition to the ocean does not require changes to land use, such as reforestation of agricultural land. Freshly deposited tephra frequently creates a barren landscape in volcanic areas, and following eruptions governments may have to invest funds to clear tephra from local infrastructure. Hence, tephra deposits can be seen as a problem that requires a solution. Nevertheless, public opinion regarding any GGR initiative is likely to be mixed (Royal Society, 2018), and it would be important to undertake public engagement to communicate the positive aspects of the approach. 
253 The 'dumping' of material in international waters is currently banned under the London

254 Convention and Protocol, but the restriction of tephra loading to shallow waters within

255 territorial waters of individual nations is less clear and would require clarification.

\section{Conclusions}

We have outlined how artificial addition of tephra to the ocean may lead to $\mathrm{C}_{\text {org }}$ sequestration and GGR, and have discussed its positive and negative aspects. The advantages of tephra dispersal in this regard are:

- tephra addition to the oceans is a natural process

- tephra is widely distributed around the world

- the technology is simple and readily available

- no repurposing of valuable land resources is required

- tephra is not a scarce resource

The key factors required to transform this hypothesis into a potentially viable GGR method are:

- optimization to achieve maximum GGR for minimal tephra loading

- identification of optimal oceanic sites

- determination of potential ecological impacts

- assessment of prime locations for sourcing tephra and optimal approaches for transporting tephra to the ocean

- assessment of the scalability and economics required to have a significant GGR impact

Based on this analysis, we suggest there is a prima facie case for further study of tephra addition to the oceans as part of the palette of strategies to achieve GGR. 


\section{References}

Arthur, M.A., Dean, W.E., Laarkamp, K., 1998. Organic carbon accumulation and preservation in surface sediments on the Peru margin. Chem. Geol. 152, 273-286. https://doi.org/10.1016/S0009-2541(98)00120-X

Bastin, J.-F., Finegold, Y., Garcia, C., Mollicone, D., Rezende, M., Routh, D., Zohner, C.M., Crowther, T.W., 2019. The global tree restoration potential. Science (80-. ). 365, 76-79. https://doi.org/10.1126/SCIENCE.AAX0848

Bohlen, L., Dale, A.W., Sommer, S., Mosch, T., Hensen, C., Noffke, A., Scholz, F., Wallmann, K., 2011. Benthic nitrogen cycling traversing the Peruvian oxygen minimum zone. Geochim. Cosmochim. Acta 75, 6094-6111. https://doi.org/10.1016/j.gca.2011.08.010

Boyd, P.W., Jickells, T., Law, C.S., Blain, S., Boyle, E.A., Buesseler, K.O., Coale, K.H., Cullen, J.J., de Baar, H.J.W., Follows, M., Harvey, M., Lancelot, C., Levasseur, M., Owens, N.P.J., Pollard, R., Rivkin, R.B., Sarmiento, J., Schoemann, V., Smetacek, V., Takeda, S., Tsuda, A., Turner, S., Watson, A.J., 2007. Mesoscale iron enrichment experiments 1993-2005: synthesis and future directions. Science 315, 612-7. https://doi.org/10.1126/science.1131669

Boyd, P.W., Watson, A.J., Law, C.S., Abraham, E.R., Trull, T., Murdoch, R., Bakker, D.C.E., Bowie, A.R., Buesseler, K.O., Chang, H., Charette, M., Croot, P., Downing, K., Frew, R., Gall, M., Hadfield, M., Hall, J., Harvey, M., Jameson, G., LaRoche, J., Liddicoat, M., Ling, R., Maldonado, M.T., McKay, R.M., Nodder, S., Pickmere, S., Pridmore, R., Rintoul, S., Safi, K., Sutton, P., Strzepek, R., Tanneberger, K., Turner, S., Waite, A., Zeldis, J., 2000. A mesoscale phytoplankton bloom in the polar Southern Ocean stimulated by iron fertilization. Nature 407, 695-702. 
Brown, A., Thatje, S., Hauton, C., 2017. The Effects of Temperature and Hydrostatic Pressure on Metal Toxicity: Insights into Toxicity in the Deep Sea. Environ. Sci. Technol. 51, 10222-10231. https://doi.org/10.1021/acs.est.7b02988

Burdige, D.J., 2007. Preservation of organic matter in marine sediments: Controls, mechanisms, and an imbalance in sediment organic carbon budgets? Chem. Rev. 107, 467-485. https://doi.org/10.1021/cr050347q

Coccioni, R., Galeotti, S., 1994. K-T boundary extinction: geologically instantaneous or gradual event? Evidence from deep-sea benthic foraminifera. Geology 22, 779-782. https://doi.org/10.1130/0091-7613(1994)022<0779:KTBEGI>2.3.CO;2

Dale, A.W., Sommer, S., Lomnitz, U., Montes, I., Treude, T., Liebetrau, V., Gier, J., Hensen, C., Dengler, M., Stolpovsky, K., Bryant, L.D., Wallmann, K., 2015. Organic carbon production, mineralisation and preservation on the Peruvian margin. Biogeosciences 12, 1537-1559. https://doi.org/10.5194/bg-12-1537-2015

Duggen, S., Croot, P., Schacht, U., Hoffmann, L., 2007. Subduction zone volcanic ash can fertilize the surface ocean and stimulate phytoplankton growth: Evidence from biogeochemical experiments and satellite data. Geophys. Res. Lett. 34, L01612. https://doi.org/10.1029/2006GL027522

Duggen, S., Olgun, N., Croot, P., Hoffmann, L., Dietze, H., Delmelle, P., Teschner, C., Skolen, A.P.M., 2010. The role of airborne volcanic ash for the surface ocean biogeochemical iron-cycle: a review, Biogeosciences.

Dunne, J.P., Sarmiento, J.L., Gnanadesikan, A., 2007. A synthesis of global particle export from the surface ocean and cycling through the ocean interior and on the seafloor. 
Eisenhour, D.D., Brown, R.K., 2009. Bentonite and its impact on modern life. Elements. https://doi.org/10.2113/gselements.5.2.83

Falkowski, P., Scholes, P.J., Boyle, E., Canadell, J., Canfield, D., Elser, J., Gruber, N., Hibbard, K., Högberg, P., Linder, S., Mackenzie, F.T., Moore III, B., Pedersen, T.,

Gieskes, J.M., 1983. The chemistry of interstitial waters of deep sea sediments: interpretation of deep sea drilling data, in: Riley, J.P., Chester, R. (Eds.), Chemical Oceanography. Academic Press, London, pp. 221-269.

Gudmundsson, M.T., Thordarson, T., Höskuldsson, Á., Larsen, G., Björnsson, H., Prata, F.J., Oddsson, B., Magnússon, E., Högnadóttir, T., Petersen, G.N., Hayward, C.L., Stevenson, J.A., Jónsdóttir, I., 2012. Ash generation and distribution from the April-May 

https://doi.org/10.1038/srep00572

Haeckel, M., van Beusekom, J., Wiesner, M.G., König, I., 2001. The impact of the 1991 Mount Pinatubo tephra fallout on the geochemical environment of the deep-sea sediments in the South China Sea. Earth Planet. Sci. Lett. 193, 151-166. https://doi.org/10.1016/S0012-821X(01)00496-4

Hamme, R.C., Webley, P.W., Crawford, W.R., Whitney, F.A., DeGrandpre, M.D., Emerson, S.R., Eriksen, C.C., Giesbrecht, K.E., Gower, J.F.R., Kavanaugh, M.T., Peña, M.A., Sabine, C.L., Batten, S.D., Coogan, L.A., Grundle, D.S., Lockwood, D., 2010. Volcanic ash fuels anomalous plankton bloom in subarctic northeast Pacific. Geophys. Res. Lett. 37, n/a-n/a. https://doi.org/10.1029/2010GL044629

Hartnett, H.E., Keil, R.G., Hedges, J.I., Devol, A.H., 1998. Influence of oxygen exposure time on organic carbon preservation in continental margin sediments. Nature $391,572-$ 575. https://doi.org/10.1038/35351

Haszeldine, R.S., Flude, S., Johnson, G., Scott, V., 2018. Negative emissions technologies and carbon capture and storage to achieve the Paris Agreement commitments. Philos. Trans. R. Soc. A Math. Eng. Sci. 376, 20160447. https://doi.org/10.1098/rsta.2016.0447

Hembury, D.J., Palmer, M.R., Fones, G.R., Mills, R.A., Marsh, R., Jones, M.T., 2012. Uptake of dissolved oxygen during marine diagenesis of fresh volcanic material. Geochim. Cosmochim. Acta 84, 353-368. https://doi.org/10.1016/J.GCA.2012.01.017

Hess, S., Kuhnt, W., 1996. Deep-sea benthic foraminiferal recolonization of the $1991 \mathrm{Mt}$. Pinatubo ash layer in the South China Sea. Mar. Micropaleontol. 28, 171-197. https://doi.org/10.1016/0377-8398(95)00080-1 
Hess, S., Kuhnt, W., Hill, S., Kaminski, M.A., Holbourn, A., de Leon, M., 2001. Monitoring the recolonization of the Mt Pinatubo 1991 ash layer by benthic foraminifera. Mar. Micropaleontol. 43, 119-142. https://doi.org/10.1016/S0377-8398(01)00025-1

Hoffmann, L.J., Breitbarth, E., Ardelan, M.V., Duggen, S., Olgun, N., Hassellöv, M., Wängberg, S.- $\AA$., 2012. Influence of trace metal release from volcanic ash on growth of Thalassiosira pseudonana and Emiliania huxleyi. Mar. Chem. 132-133, 28-33. https://doi.org/10.1016/J.MARCHEM.2012.02.003

Homoky, W.B., Hembury, D.J., Hepburn, L.E., Mills, R.A., Statham, P.J., Fones, G.R., Palmer, M.R., 2011. Iron and manganese diagenesis in deep sea volcanogenic sediments and the origins of pore water colloids. Geochim. Cosmochim. Acta 75, 5032-5048. https://doi.org/10.1016/J.GCA.2011.06.019

IPCC, 2018. Summary for Policymakers, in: Masson-Delmotte, V., Zhai, P., Pörtner, H.O., Roberts, D., Skea, J., Shukla, P.R., Pirani, A., Chen, Y., Connors, S., Gomis, M., Lonnoy, E., Matthews, J.B.R., Moufouma-Okia, W., Péan, C., Pidcock, R., Reay, N., Tignor, M., Waterfield, T., Zhou, X. (Eds.), Global Warming of $1.5^{\circ} \mathrm{C}$. An IPCC Special Report on the Impacts of Global Warming of $1.5^{\circ} \mathrm{C}$ above Pre-Industrial Levels and Related Global Greenhouse Gas Emission Pathways, in the Context of Strengthening the Global Response to the Threat of Climate Change,. World Meteorological Organization, Geneva, p. 32. https://doi.org/10.1017/CBO9781107415324

Jones, M.T., Gislason, S.R., 2008. Rapid releases of metal salts and nutrients following the deposition of volcanic ash into aqueous environments. Geochim. Cosmochim. Acta 72, 3661-3680. https://doi.org/10.1016/j.gca.2008.05.030

Kheshgi, H.S., 1995. Sequestering atmospheric carbon dioxide by increasing ocean alkalinity. Energy 20, 915-922. https://doi.org/10.1016/0360-5442(95)00035-F 
Kuhnt, W., Hess, S., Holbourn, A., Paulsen, H., Salomon, B., 2005. The impact of the 1991 Mt. Pinatubo eruption on deep-sea foraminiferal communities: A model for the Cretaceous-Tertiary (K/T) boundary? Palaeogeogr. Palaeoclimatol. Palaeoecol. 224, 83-107. https://doi.org/10.1016/J.PALAEO.2005.03.042

Lalonde, K., Mucci, A., Ouellet, A., Gélinas, Y., 2012. Preservation of organic matter in sediments promoted by iron. Nature 483, 198-200. https://doi.org/10.1038/nature10855

Langmann, B., Zakšek, K., Hort, M., Duggen, S., 2010. Volcanic ash as fertiliser for the surface ocean, Atmos. Chem. Phys.

Lin, I.I., Hu, C., Li, Y.H., Ho, T.Y., Fischer, T.P., Wong, G.T.F., Wu, J., Huang, C.W., Chu, D.A., Ko, D.S., Chen, J.P., 2011. Fertilization potential of volcanic dust in the lownutrient low-chlorophyll western North Pacific subtropical gyre: Satellite evidence and laboratory study. Global Biogeochem. Cycles 25. https://doi.org/10.1029/2009GB003758

Lomax, G., Workman, M., Lenton, T., Shah, N., 2015. Reframing the policy approach to greenhouse gas removal technologies. Energy Policy 78, 125-136. https://doi.org/10.1016/j.enpol.2014.10.002

Longman, J., Palmer, M.R., Gernon, T.M., Manners, H.R., 2019. The role of tephra in enhancing organic carbon preservation in marine sediments. Earth-Science Rev. https://doi.org/10.1016/J.EARSCIREV.2019.03.018

Martin, J.H., Fitzwater, S.E., 1988. Iron deficiency limits phytoplankton growth in the northeast pacific subarctic. Nature 331, 341-343. https://doi.org/10.1038/331341a0

Maters, E.C., Delmelle, P., Gunnlaugsson, H.P., 2017. Controls on iron mobilisation from volcanic ash at low pH: Insights from dissolution experiments and Mössbauer 
spectroscopy. Chem. Geol. 449, 73-81. https://doi.org/10.1016/J.CHEMGEO.2016.11.036

Mathers, J., Craft, E., Norsworthy, M., Wolfe, C., 2014. Green Freight Handbook. Enironmental Defense Fund, New York.

Matter, J.M., Stute, M., Snæbjörnsdottir, S.Ó., Oelkers, E.H., Gislason, S.R., Aradottir, E.S., Sigfusson, B., Gunnarsson, I., Sigurdardottir, H., Gunnlaugsson, E., Axelsson, G., Alfredsson, H.A., Wolff-Boenisch, D., Mesfin, K., Fernandez de la Reguera Taya, D., Hall, J., Dideriksen, K., Broecker, W.S., 2016. Rapid carbon mineralization for permanent disposal of anthropogenic carbon dioxide emissions. Science 352, 1312-4. https://doi.org/10.1126/science.aad8132

Mélançon, J., Levasseur, M., Lizotte, M., Delmelle, P., Cullen, J., Hamme, R.C., Peña, A., Simpson, K.G., Scarratt, M., Tremblay, J.-É.É., Zhou, J., Johnson, K., Sutherland, N., Arychuk, M., Nemcek, N., Robert, M., 2014. Early response of the northeast subarctic Pacific plankton assemblage to volcanic ash fertilization. Limnol. Oceanogr. 59, 55-67. https://doi.org/10.4319/lo.2014.59.1.0055

Murray, N.A., McManus, J., Palmer, M.R., Haley, B., Manners, H., 2018. Diagenesis in tephra-rich sediments from the Lesser Antilles Volcanic Arc: Pore fluid constraints. Geochim. Cosmochim. Acta 228, 119-135. https://doi.org/10.1016/J.GCA.2018.02.039

Olgun, N., Duggen, S., Croot, P.L., Delmelle, P., Dietze, H., Schacht, U., Óskarsson, N., Siebe, C., Auer, A., Garbe-Schönberg, D., 2011. Surface ocean iron fertilization: The role of airborne volcanic ash from subduction zone and hot spot volcanoes and related iron fluxes into the Pacific Ocean. Global Biogeochem. Cycles 25, n/a-n/a. https://doi.org/10.1029/2009GB003761

Pabortsava, K., Lampitt, R.S., Benson, J., Crowe, C., McLachlan, R., Le Moigne, F.A.C., 
Pennington, J.T., Mahoney, K.L., Kuwahara, V.S., Kolber, D.D., Calienes, R., Chavez, F.P., 2006. Primary production in the eastern tropical Pacific: A review. Prog. Oceanogr. 69, 285-317. https://doi.org/10.1016/j.pocean.2006.03.012

Perrier, V., Meidla, T., Tinn, O., Ainsaar, L., 2012. Biotic response to explosive volcanism: Ostracod recovery after Ordovician ash-falls. Palaeogeogr. Palaeoclimatol. Palaeoecol.

Ramage, M.H., Burridge, H., Busse-Wicher, M., Fereday, G., Reynolds, T., Shah, D.U., Wu, 365-366, 166-183. https://doi.org/10.1016/j.palaeo.2012.09.024

Renforth, P., Henderson, G., 2017. Assessing ocean alkalinity for carbon sequestration. Rev. Geophys. 55, 636-674. https://doi.org/10.1002/2016RG000533

Royal Society, T., 2018. Greenhouse Gas Removal. Royal Society, London.

Rubin, M., Berman-Frank, I., Shaked, Y., 2011. Dust- and mineral-iron utilization by the marine dinitrogen-fixer Trichodesmium. Nat. Geosci. 4, 529-534. Press.

Schrag, D.P., Higgins, J.A., Macdonald, F.A., Johnston, D.T., 2013. Authigenic carbonate and the history of the global carbon cycle. Science (80-. ). 339, 540-3. 
Scudder, R.P., Murray, R.W., Schindlbeck, J.C., Kutterolf, S., Hauff, F., Underwood, M.B., Gwizd, S., Lauzon, R., McKinley, C.C., 2016. Geochemical approaches to the quantification of dispersed volcanic ash in marine sediment. Prog. Earth Planet. Sci. 3,

Siegenthaler, U., Sarmiento, J.L., 1993. Atmospheric carbon dioxide and the ocean. Nature. 1. https://doi.org/10.1186/s40645-015-0077-y

Steffen, W., Rockström, J., Richardson, K., Lenton, T.M., Folke, C., Liverman, D.,

Tollefson, J., 2018. IPCC says limiting global warming to $1.5^{\circ} \mathrm{C}$ will require drastic action. Nature 562, 172-173. https://doi.org/10.1038/d41586-018-06876-2

Uematsu, M., Toratani, M., Kajino, M., Narita, Y., Senga, Y., Kimoto, T., 2004. Enhancement of primary productivity in the western North Pacific caused by the eruption of the Miyake-jima Volcano. Geophys. Res. Lett. 31, n/a-n/a. https://doi.org/10.1029/2003g1018790

UNCTAD, 2018. Review of Maritime Transport. United Nations, New York and Geneva.

Wall-Palmer, D., Jones, M.T., Hart, M.B., Fisher, J.K., Smart, C.W., Hembury, D.J., Palmer, M.R., Fones, G.R., 2011. Explosive volcanism as a cause for mass mortality of pteropods. Mar. Geol. 282, 231-239. https://doi.org/10.1016/J.MARGEO.2011.03.001

Zahariev, K., Christian, J.R., Denman, K.L., 2008. Preindustrial, historical, and fertilization 


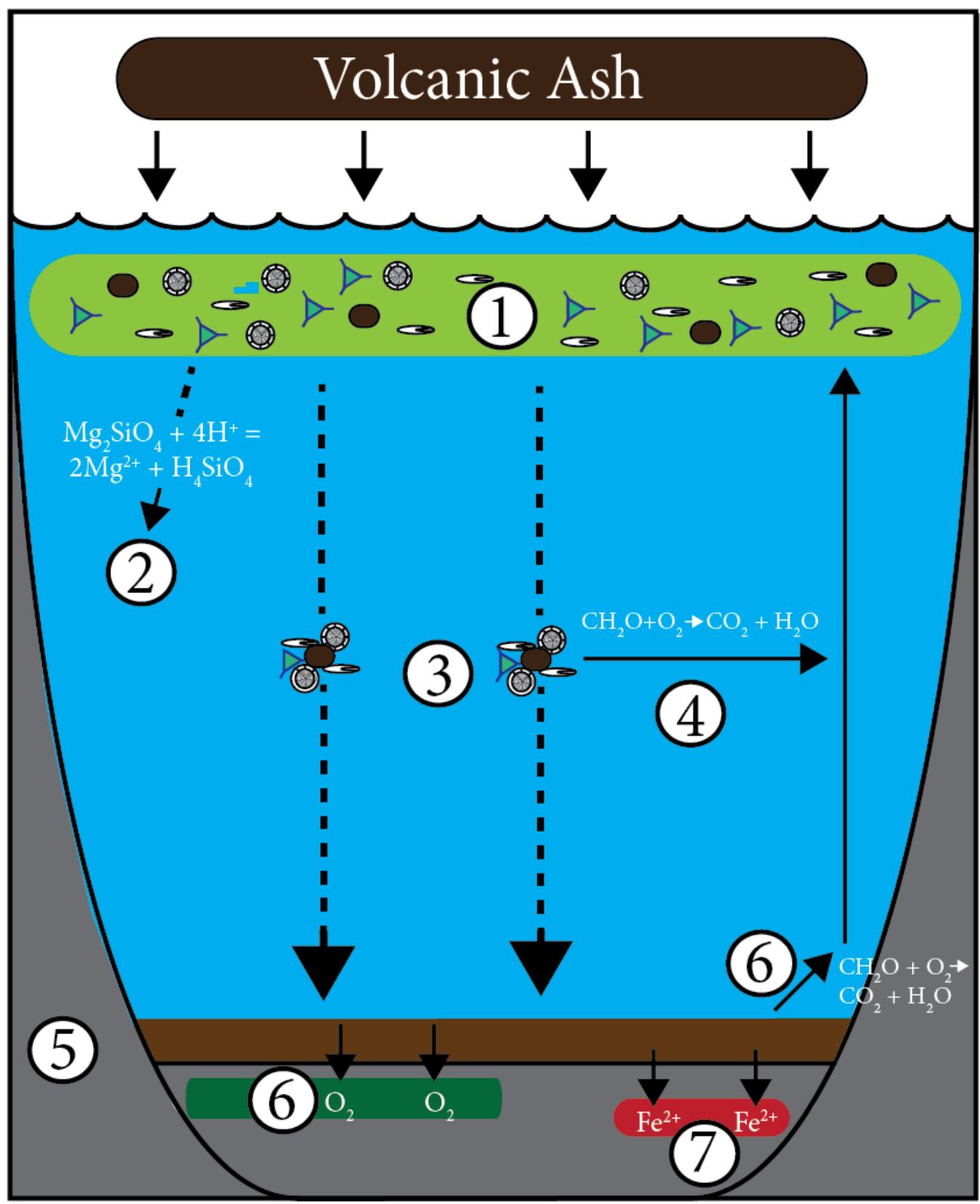

Figure 1: Schematic image detailing the processes which may occur to enhance carbon sequestration and greenhouse gas removal via the addition of volcanic ash to the ocean. 1) The fertilization of phytoplankton blooms in the upper ocean. 2) The release of $\mathrm{Mg}^{2+}\left(\right.$ and $\left.\mathrm{Ca}^{2+}\right)$ ions to the ocean, via the dissolution of minerals contained in the ash. Here we use the dissolution of olivine as an example. $\mathrm{Mg}^{2+}$ are released during this process which consumes $\mathrm{H}^{+}$ions, thus increasing alkalinity. 3) The transfer of organic carbon from the upper to lower ocean (the biological pump), enhanced by the 
association of phytoplankton to ash particles. 4) The remineralization of some organic matter during transport through an oxygenated water column 5) The formation of a volcanic ash layer at the sediment-water interface. 6) Removal of $\mathrm{O}_{2}$ from organic-rich sediments and formation of anoxic conditions, reducing organic carbon oxidation and remineralization. 7) The release of reactive species of $\mathrm{Fe}, \mathrm{Mn}$ and $\mathrm{Al}$, available to bind to organic carbon and reduce oxidation.
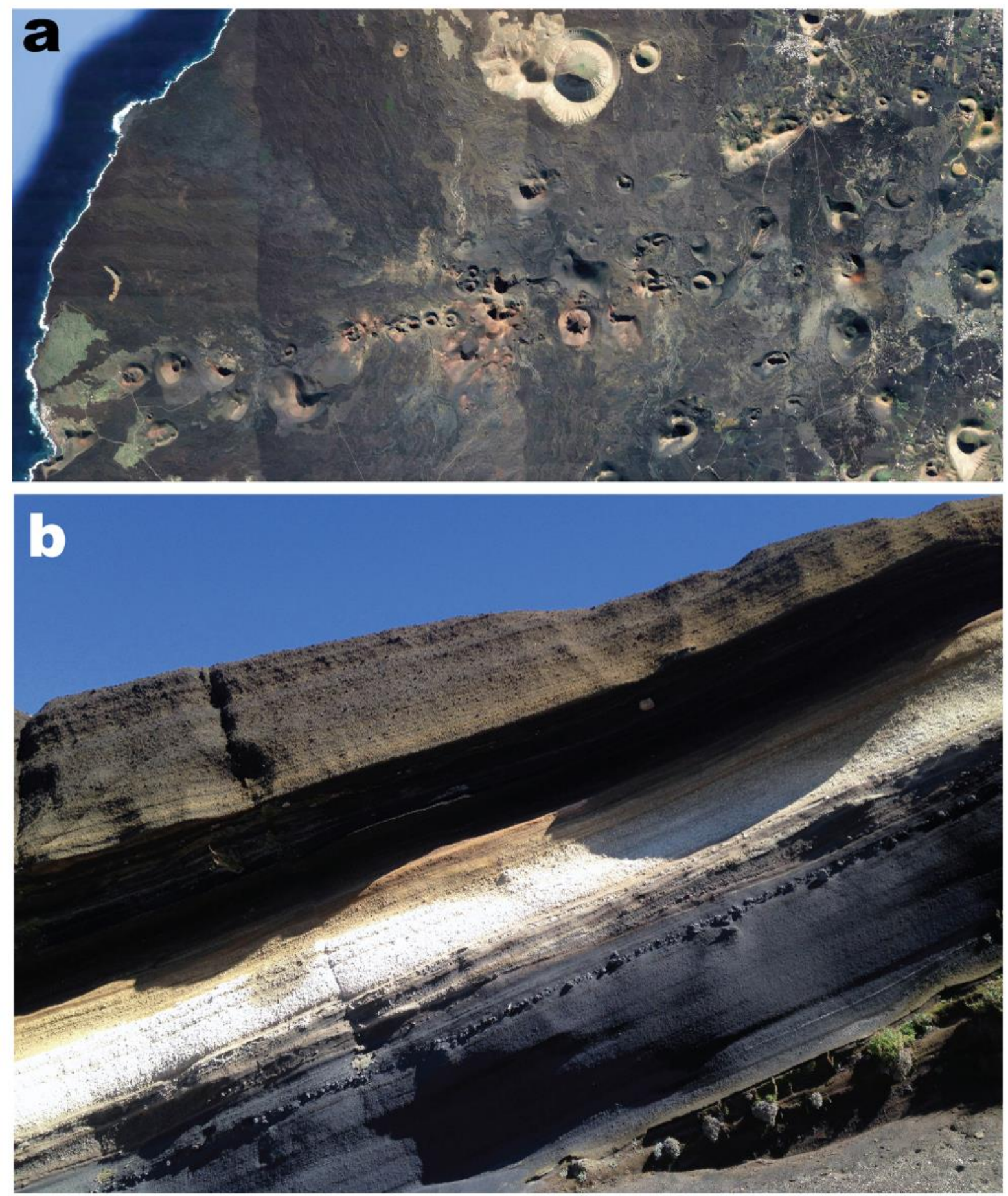

Figure 2: Examples of Holocene-age tephra in the natural environment. Panel a is an aerial image of cinder cone volcanoes in Lanzarote (Canary Islands), displaying both the extensive tephra fields surrounding them and their proximity to the ocean. Panel $b$ is an example of bedded tephra deposits from Tenerife (also Canary Islands). 


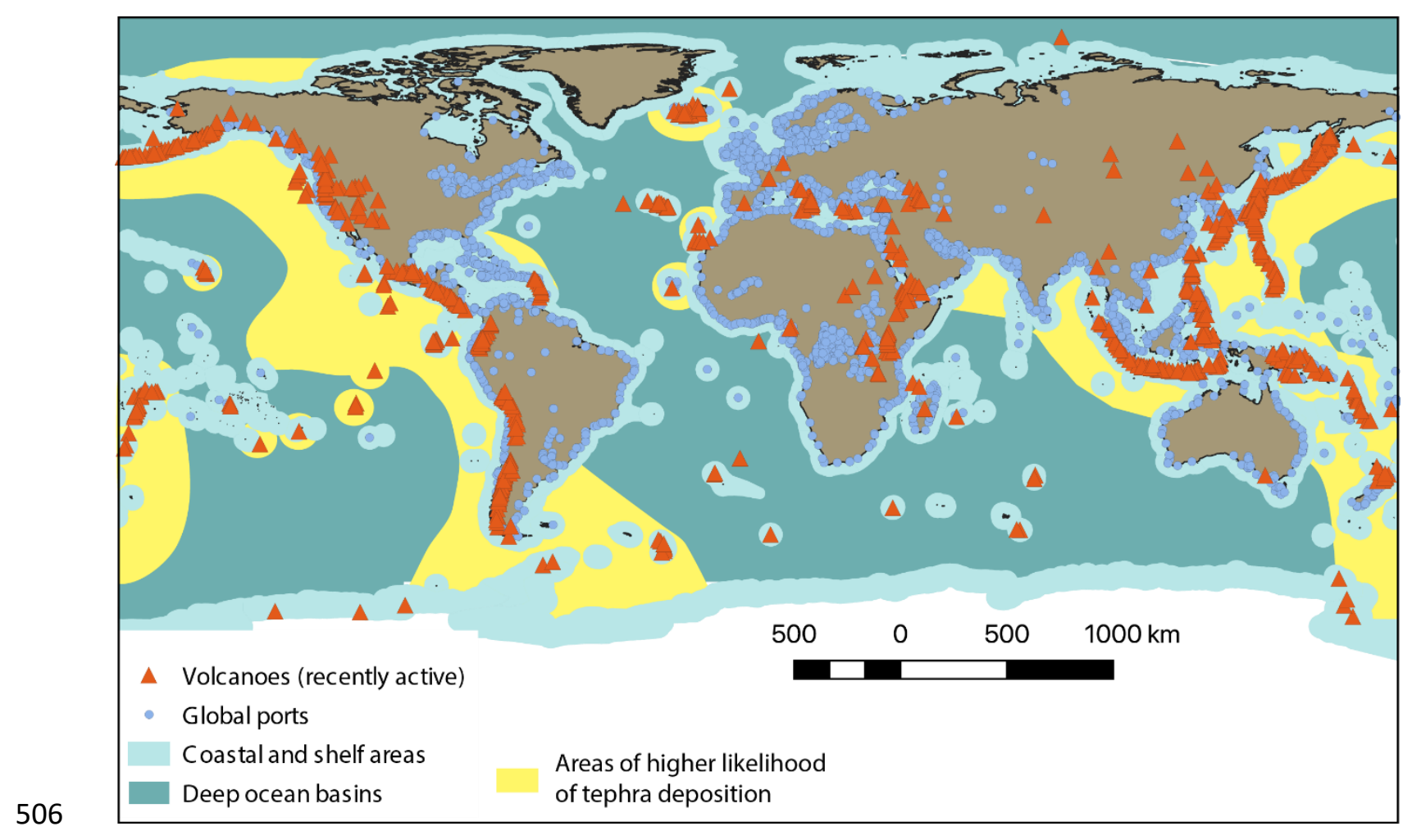

507 Figure 3: Global map displaying the location of all active (and recently active) volcanoes (red 508 triangles), and of global ports (blue circles) Also indicated is regions in which tephra deposition is 509 considered highly likely (yellow), from Olgun et al., 2011. Most volcanoes are located either on, or 510 close to the ocean, and very few are a significant distance from major ports. Also displayed are the 511 extent of coastal and shelf seas (those which are $<200 \mathrm{~m}$ in depth), which would be the target for 512 offshore tephra addition. 
Table 1: Estimates of gross and net potential $\mathrm{CO}_{2}$ storage. ${ }^{\mathrm{a}}$ Typical $\mathrm{CO}_{2}$ equivalent fluxes are calculated from the POC rain rate of Site 1 from the inner Peruvian shelf (Dale et al., 2015). ${ }^{\mathrm{b}}$ Burial efficiencies are taken from the average carbon burial efficiency of sites 1 and 2 of the inner Peru shelf, with OMZ carbon burial efficiencies an average of sites 6-8 (Dale et al., 2015). ${ }^{\mathrm{c}}$ Mass of tephra with a density of $1400 \mathrm{~kg} \mathrm{~m}^{3}$ (a typical value of tephra; Gudmundsson et al., 2012) and $50 \%$ porosity (Hembury et al., 2012) required per square meter of seafloor. ${ }^{\mathrm{d}}$ Bulk carrier capacity from Freese, 2017. ${ }^{\mathrm{e}}$ Yearly $\mathrm{CO}_{2}$ equivalent flux to the area covered by tephra. ${ }^{\mathrm{f}}$ Gross increase in $\mathrm{CO}_{2}$ preserved in sediment achieved by reducing remineralization by $29 \%$. ${ }^{\mathrm{g}}$ Estimate of onshore $\mathrm{CO}_{2}$ emissions, calculated assuming truck size of 44 tonnes (typical articulated lorry load size) an average distance of $30 \mathrm{~km}$ from tephra source to port, 1140 journeys necessary to carry 50,000 tonnes of tephra, and using the EDF's green freight calculator (Mathers et al., 2014). ${ }^{\text {h }}$ Estimate of offshore $\mathrm{CO}_{2}$ emissions, calculated from values in Freese, 2017. ${ }^{\mathrm{j}} \mathrm{Net}^{\mathrm{CO}_{2}}$ storage calculated via subtraction of onshore and offshore $\mathrm{CO}_{2}$ emissions from gross storage.

Gross potential $\mathrm{CO}_{2}$ storage Value

Typical inner Peru shelf $\mathrm{C}_{\text {org }}$ burial rate $79.5 \mathrm{mmol} \mathrm{m}^{-2} \mathrm{~d}^{-1} \mathrm{a}$

Yearly $\mathrm{C}_{\text {org }}$ flux to sediments $348.52 \mathrm{gC} \mathrm{m}^{-2} \mathrm{yr}^{-1 \mathrm{a}}$

$\mathrm{CO}_{2}$ equivalent flux to sediments $1277 \mathrm{gCO}_{2} \mathrm{~m}^{-2} \mathrm{yr}^{-1 \mathrm{a}}$

Typical Peru shelf burial efficiency $18 \%^{\mathrm{b}}$

Typical Peru shelf burial efficiency below Oxygen Minimum Zone $47 \%$

Likely increase in burial efficiency as a result of $\mathrm{O}_{2}$ depletion

\section{Resource requirement}

Thickness of tephra applied to sediment

$0.5 \mathrm{~cm}$

Volume of tephra required per square meter $5 \times 10^{3} \mathrm{~cm}^{3} \mathrm{~m}^{-2}$

Mass of tephra (50\% porosity)

$6.7 \times 10^{3} \mathrm{~g} \mathrm{~m}^{-2 \mathrm{c}}$

Assumed bulk carrier capacity $50,000 \mathrm{t}^{\mathrm{d}}$

Area covered per carrier load $7.5 \times 10^{6} \mathrm{~m}^{2 \mathrm{c}}$

Yearly supply of carbon to this area before remineralization $2.61 \times 10^{9} \mathrm{gC} \mathrm{yr}^{-1 \mathrm{e}}$

Gross $\mathrm{CO}_{2}$ storage per load per year for $29 \%$ reduction of $2777 \mathrm{t} \mathrm{CO}_{2}{ }^{\mathrm{f}}$ remineralization

\section{$\mathrm{CO}_{2}$ emissions associated}

$\mathrm{CO}_{2}$ emitted by 44 tonne truck (per tonne load and km travelled)

Distance from tephra source to port $30 \mathrm{~km}^{\mathrm{g}}$

Number of journeys $\sim 1140^{\mathrm{g}}$

$\mathrm{CO}_{2}$ emitted per 50,000 tonnes tephra transported to port 
$\mathrm{CO}_{2}$ emitted by carrier (per tonne load and $\mathrm{km}$ travelled)

$\mathrm{CO}_{2}$ emitted by $50,000 \mathrm{t}$ bulk carrier

Distance to and from load port, and tephra spreading

$\mathrm{CO}_{2}$ emitted per carrier load

\author{
$3 \mathrm{gCO}_{2} \mathrm{t}^{-1} \mathrm{~km}^{-1 \mathrm{~h}}$ \\ $150 \times 10^{3} \mathrm{gCO}_{2} \mathrm{~km}^{-1 \mathrm{~h}}$ \\ $2000 \mathrm{~km}^{\mathrm{i}}$ \\ $300 \mathrm{t} \mathrm{CO}_{2}{ }^{\mathrm{h}}$
}

Net $\mathrm{CO}_{2}$ storage per load

$2341 \mathrm{tCO}_{2}^{\mathrm{j}}$

529

530

531

532

533

534

535

536

Table 2: Comparison of removal potential and costs, alongside technology readiness levels (TRLs) of other proposed GGR methods, and enhanced tephra loading. Table adapted from Royal Society (2018), with additional data from this study. ${ }^{a}$ Estimates of global potential for $\mathrm{CO}_{2}$ removal from tephra loading taken from Longman et al. (2019). There are 9 TRLs describing maturity of technology: TRL1 basic principles, TRL2 invention and research, TRL3 proof of concept, TRL4 bench scale research, TRL5 pilot scale, TRL6 large scale, TRL7 inactive commissioning, TRL8 active commissioning and TRL9 operations.

\begin{tabular}{|c|c|c|c|}
\hline GGR Method & $\frac{\text { Global } \mathrm{CO}_{2} \text { removal }}{\text { potential }\left(\mathrm{Gt} \mathrm{CO} \mathrm{CO}^{-1}\right)}$ & $\begin{array}{l}\text { Cost per } \\
\underline{\mathrm{tCO}} \mathrm{O}_{2}(\mathrm{US} \$)\end{array}$ & $\begin{array}{l}\text { Technology } \\
\text { readiness } \\
\text { level (TRL) }\end{array}$ \\
\hline $\begin{array}{l}\text { Afforestation, reforestation and forest } \\
\text { management }\end{array}$ & $\begin{array}{l}\text { Afforestation/reforestation: } \\
3-20 \text {, forest management: } \\
1-2\end{array}$ & $3-30$ & $8-9$ \\
\hline $\begin{array}{l}\text { Wetland, peatland and coastal habitat } \\
\text { restoration }\end{array}$ & $0.4-20$ & $10-100$ & $5-6$ \\
\hline Soil carbon sequestration & $1-10$ & $\begin{array}{l}10 \text { profit, } 3 \\
\text { cost }\end{array}$ & $8-9$ \\
\hline Biochar & $2-5$ & $0-200$ & $3-6$ \\
\hline Ocean fertilization & $1-3$ & $10-500$ & $1-5$ \\
\hline Enhanced terrestrial weathering & $0.5-4$ & $50-500$ & $1-5$ \\
\hline Mineral carbonation & - & $\begin{array}{l}50-300(\text { ex } \\
\text { situ), } 20 \text { (in } \\
\text { situ) }\end{array}$ & $3-8$ \\
\hline Ocean Alkalinity & 40 & $70-200$ & $2-4$ \\
\hline Offshore tephra loading & $0.88^{a}$ & $\sim 55$ & $2-4$ \\
\hline
\end{tabular}

